\title{
Bacteria-nanoparticle interaction based on functionalized surfaces
}

\author{
Maiara Emer (IC), Mateus B. Cardoso (PQ).
}

\begin{abstract}
Silica nanoparticles were synthesized and functionalized with different chemical groups (hydroxyl, mercapto, isocyanate, carboxyl and amino) in order to understand how different functional groups favor the interaction between nanoparticles and the envelope of different bacteria. Obtained results showed that bacteriananoparticle interation is driven by the nature of nanoparticles surface and that different types of bacteria envelope do not influence this mechanism.
\end{abstract}

Nanometric structures, functionalization, bacteria interaction.

\section{Introduction}

Nanoparticles are being used as one of the most promising strategies to prevent bacterial growth and development. Due to their unique physicochemical properties, nanomaterials are able to interact intimately with bacteria. Therefore, this mechanism of interaction has been still unknown. ${ }^{1-2}$ It is believed that it depends on the properties of the nanoparticles (such as size, aggregation state and functionalization of its surface) and also on the organization of the constituents of the bacterial cell envelope. ${ }^{3}$

\section{Results and Discussion}

Quantification of chemical groups present on the silica surface was determined by thermogravimetric analysis through distinct weight loss stages (Figure $1 \mathrm{~A}$ ). For $\mathrm{SiO}_{2}-\mathrm{OH}$ and $\mathrm{SiO}_{2-}$ $\mathrm{NH}_{2}$ samples, the weight loss between $180^{\circ} \mathrm{C}$ and $700{ }^{\circ} \mathrm{C}$ is $\sim 4.2 \%$ and $\sim 5.6 \%$, respectively. The difference $\sim 1.4 \%$ between these samples is related to the $-\mathrm{NH}_{2}$ group incorporated on the material surface. This is also valid for $\mathrm{SiO}_{2}-\mathrm{NCO}$ and $\mathrm{SiO}_{2}-\mathrm{SH}$ samples, which showed $\sim 2.1 \%$ and $\sim 4.2 \%$ of $-\mathrm{NCO}$ and $-\mathrm{SH}$ groups, respectively. For $\mathrm{SiO}_{2}-\mathrm{COOH}$, taking into account that $\mathrm{SiO}_{2} \mathrm{NPs}-\mathrm{NH}_{2}$ were used as precursor for the synthesis, the difference between the weight loss of $\mathrm{SiO}_{2}-\mathrm{NH}_{2}$ and $\mathrm{SiO}_{2}-\mathrm{COOH}$ is $~ 9.5 \%$ related to $-\mathrm{COOH}$ group. FTIR spectra (Figure 1B) confirms the functionalization success where bands attributed do different chemical groups can be identified. Incubation experiments (Figure $1 \mathrm{C}$ and 1D) with Staphylococcus aureus and Escherichia coli bacterium showed the following bactericidal efficiency trend: $\mathrm{SiO}_{2}-\mathrm{OH}>\mathrm{SiO}_{2}-\mathrm{COOH}>\mathrm{SiO}_{2}-$ $\mathrm{NH}_{2}>\mathrm{SiO}_{2}-\mathrm{SH}>\mathrm{SiO}_{2}-\mathrm{NCO}$. Bare nanoparticles and aliquots of nanoparticles incubated with bacteria were analyzed by scanning electron microscopy (SEM) and are presented in Figures $1 \mathrm{E}, 1 \mathrm{~F}$ and $1 \mathrm{G}$.
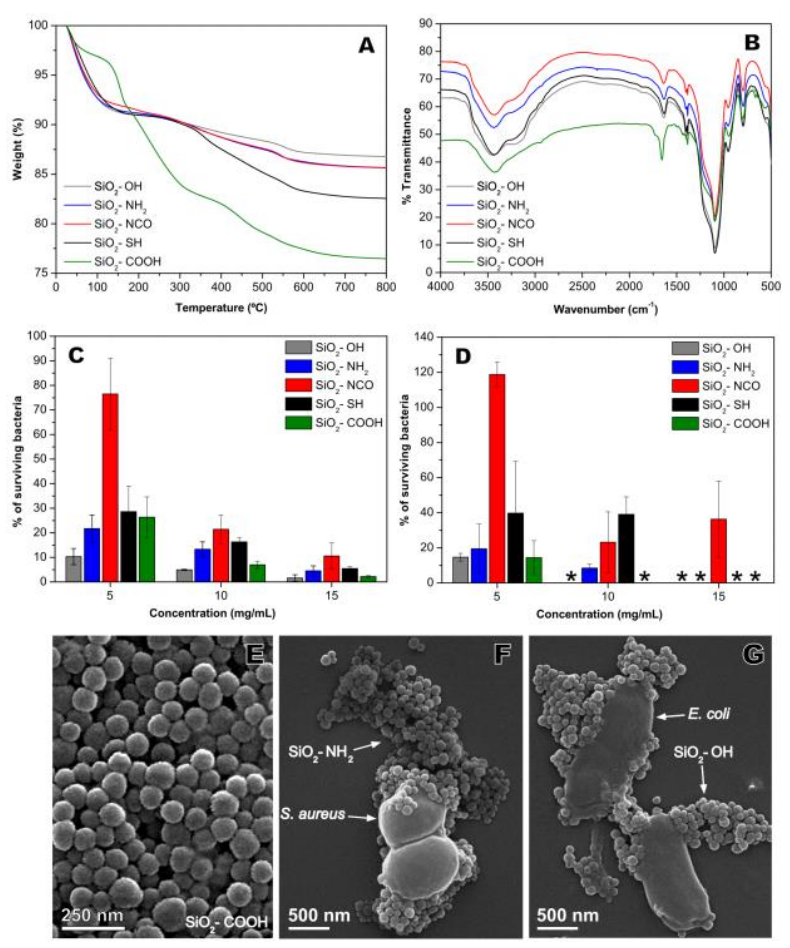

Figure 1. Results obtained for silica nanoparticles synthesis.

\section{Conclusions}

Bacteria-nanoparticle interation is extremely dependent on the the nature of nanoparticles surface which can be tailored to obtain strucutures with high batericidadal efficacy. Similar behaviors were seen when different types of bacteria cell envelopes where compared.

\section{Acknowledgement}

We thank Fapesp (Project numbers 2014/01241-4 and 2014/22322-2), LNLS, LNBio and LNNano.

\footnotetext{
${ }^{1}$ Gilbert, P.; et al. Antimicrob Agents and Chemotherapy. 1990, 34, 1865-1868.

${ }^{2}$ Darouiche, R. O.; et al. J. Med. 2004, 350, 1422-1429.

${ }^{3}$ Aruguete, D. M.; et al. Environ Chem. 2010, 7, 3-9.
} 